Письменные памятники Востока. 2021. Том 18. № 3 (вып. 46). С. 148-159

\title{
Miscellany on the Tumshuqese Documents: Part II
}

\author{
OGIHARA Hirotoshi \\ The University of Tokyo, \\ Graduate School of Humanities and Sociology (Linguistics) \\ Tokyo, Japan \\ Centre de recherche sur les civilisations de l'Asie orientale (CRCAO), \\ Paris, France
}

DOI: $10.17816 / \mathrm{WMO} 77877$

Abstract: The present article is part of the research on Tumshuqese (for Part I see Central Asiatic Journal, 2020, vol. 63, no. 1-2. pp. 11-24). Among Middle Iranian languages, linguistic research on Tumshuqese has been much delayed because of the insufficient documentation, and the lack of the parallel texts written in other languages which leads to the comparative study. However, the secular documents, especially the contracts, are the most important material for the linguistic study of this language in view of the fact [1] that Tumshuqese contracts offer the best preserved texts and [2] that some passages are comparable to the contracts written in other Central Asian languages. In this paper, an attempt will be made to elucidate following Tumshuqese words attested in the secular documents: the numerals $t$ shārsa 'forty', hodad ${ }_{1} a$ 'seventy', $\operatorname{sod}_{1} u$ 'hundred', $d r d_{1} a$ - 'third' and words of measure $j a h a$ - and $k^{h} a a$ - in addition to a noun dau/do 'gift'. Among them, the numerals tshārsa 'forty' and $\operatorname{hodad}_{1} a$ 'seventy' are recognized for the first time. Although other words have been more or less known to scholars, different meaning and/or analysis have been assigned to them.

Key words: Middle Iranian languages, Central Asia, secular documents, contracts, numerals, words of measure.

Acknowledgements: This contribution is dedicated as a token of my gratitude to Prof. Irina F. Popova, who has kindly supported my research on Central Asian fragments preserved in the Institute of Oriental Manuscripts of the Russian Academy of Sciences (IOM, RAS) since 2008. I would also like to express my deepest gratitude to Prof. Duan Qing, who kindly made me available the electronic typesetting of the edition of two newly found Tumshuqese documents (Duan 2021).

For citation: Hirotoshi Ogihara. "Miscellany on the Tumshuqese Documents: Part II". Pis'mennye pamiatniki Vostoka, 2021, vol. 18, no. 3 (iss. 46), pp. 148-159 (in English). DOI: 10.17816/WMO77877

About the author: OGIHARA Hirotoshi, Research Fellow of The University of Tokyo, Graduate School of Humanities and Sociology (Linguistics) (Tokyo, Japan). Membre associé of Centre de recherche sur les civilisations de l'Asie orientale (Paris, France) (diyuanyumin@gmail.com). 


\section{Introduction}

The linguistic structure of Tumshuqese, one of the Middle Iranian languages most closely related to Khotanese, has been elucidated ambiguously despite of some newly found materials. However, as it was revealed by previous studies (Hitch 1988, 1990, 1992, TPR, Ogihara \& Ching 2014, Ogihara \& Ching 2017, Ching 2019, Ogihara 2019, 2020) the secular documents, especially the contracts, are still the most important corpus for linguistic study of this language. In this paper, which is the sequel of my article on the Tumshuqese documents (Ogihara 2020), I will treat some words attested in the Tumshuqese secular documents that have been scarcely discussed in the previous studies. My discussion concerns some passages attested in the Central Asian fragments preserved in IOM, RAS, which were made available to me thanks to the arrangement by our honorand.

\section{1. $d a u / d o=$ sg. acc. of $d \bar{a}-$ 'gift'}

As mentioned by Maue (Maue 2009), three fragments in the Paris collection have been identified with the Vessantara-jātaka and they belong to one single folio. ${ }^{1}$ It is noteworthy to mention that two more Kuchean fragments kept in the Russian collection, the present inventory number of which are SI 2962-2 and SI 2998-8, were recently identified with this jātaka, and the Kuchean version of this story cannot be attributed to any known Indic texts, but rather most often exhibits similarities with the Chinese and Sogdian versions (Ogihara 2018: e9-e22 and 2021). In this text, a word dau is clearly read, and the meaning 'gift' could be assigned to it, based on the context where it appears.

HL 27b3-4: ] (handa)ranu dau ärdī $t^{h} \times[\ldots]$ bārzi rende

'[...] whoever(?) does donation to others, in that case(?) [...] he shall become a Buddha.'

\section{HL 27b5: ] (ha)nd(a)ranu dau arū ' [...] I shall do/did donation to others.'}

The former passage is comparable to the following Kuchean version.

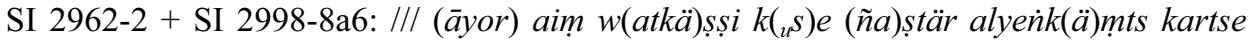
rìtatär sū pañäkte mäs(ketär) ///

'[...] whoever will give alms, order (alms), want and long for the welfare of others, he shall become a Buddha [...]'

From the morphological point of view, Tumsh. dau can be regarded as the sg. acc. form of $d \bar{a}$ - 'gift', which is etymologically related to OA neuter noun $d \bar{a} h$ - 'gift'. The Tumshuqese locution dau ar- could mean 'to donate'.

\footnotetext{
${ }^{1}$ Tumshuqese fragments known to scholars by 2009 are quoted by HL number offered by Maue (2009). On the other hand, four documents published by Ogihara and Ching (2013) and TPR are mentioned by TX001-004, and H111 is used for the recently published Tumshuqese contract (see Duan 2021). The Tumshuqese and Kuchean (i.e. Tocharian B) texts quoted in this paper are from my transliteration based on the original fragments. The following signs proposed by Maue (Maue 2009) are used for Tumshuqese. The brackets [ ] placed at the beginning or end of a quoted passage indicate a textual loss at left or right edge of a fragment. One single illegible akșara is indicated by + , and damaged part of an akșara (vowel or consonant) is indicated by $\times$. Round bracket is used for the restored part by me. $\downarrow, \mid$ and —indicate the punctuation given in the Tumshuqese documents. $\mathrm{A}$ is the akșara erased by the scribe, and $<>$ is the akșara added below a line. For the missing part of the fragment, [...] is used, but this sign is also used in the translation to indicate the part which I cannot understand. The $<\mathrm{h}>$ appeared in the consonant cluster is noted by the normal $\mathrm{h}<\mathrm{Ch}>$, while the aspirated consonant is noted by the superscript $<\mathrm{C}^{\mathrm{h}}>$.

${ }^{2}$ In Khotanese, the words for 'gift' are dāmgyā- $(<*$ dānač̄- $<d \bar{a}-$ 'to give') and haura- $(<$ haur-/hor- 'to give') = Tumsh. rura- 'gift(?)'. On the etymology of Khot. dāmgyā- and haura-, see DKS: 155-156 and 499.
} 
In addition, considering that the vowel /au/ changed into /o/ in a later stage of Tumshuqese as reflected in the declension of the $-a a$ - stem nouns and variants of some words, a thus far attested form $d o$ could be the late form of this $d a u .^{3}$ In fact, as far as the verbs remain, Tumsh. $d o$ can be regarded as a direct object of the verbs ar- 'to do' [HL 10.7] and reșt t $^{h}$ 'to send' [HL 14.9], and the context does not contradict this meaning. ${ }^{4}$

HL 10.7: cu șe azu do daro aru biśu me xšanda bujid ${ }_{1} i$

'That I have done donation(?) for a long time(?), thee (lit. my lord) knows (it) in full.,

HL 14.9: puṣtā tirye pad $_{1}$ esa do ma reșt $^{h}$ ed ${ }_{1}$ a

'Let (one) not do donation to pușta(?) in any manners(?).'

\section{Numerals}

\section{2-1. Tumsh. tshārsa 'forty'}

New numerals are attested in another fragment kept in the Paris collection. The context suggests that it is a part of a monastic account, both sides of which are written in a writing brush like other Tumshuqese documents.

HL 29b5: | cantadewā brārā tshārsa ba(ri) [

'[...] brought(3sg.) [...] to a brother of Cantadewa, 40 [...]'

Tumsh. tshārsa can be regarded as an expected form for 'forty', cf. Tumsh. tshāri 'four', Tumsh. dase 'ten' and Khot. tcaholsä/tcoholsä 'forty'. On the other hand, in the joint article with Maue (Maue \& Ogihara 2017), we interpreted Tumsh. $x_{8} \bar{a} r s u$ as the numeral 'forty', mainly based on the context, the corresponding Khotanese form, and the phonological system of Tumshuqese.

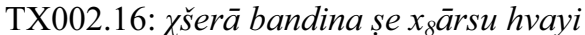

'He is to be beaten [with] 40 [strokes] as the punishment of the state'.

As suggested there, if our equation of $\left\langle\mathrm{x}_{8}\right\rangle$ with the phoneme $/ \mathrm{dz} /$ is correct, Tumsh. $d z \bar{a} r s u$ (previously transliterated as $x_{8} \bar{a} r s u$ ) would be a secondary form created by the analogy on another numeral, ex. drisu 'thirty'.

\footnotetext{
${ }^{3}$ The fact that the spelling <au> appears most often in the Buddhist texts, especially in the Karmavācanā text [HL 16], suggests that the vowel /au/ changed into /o/ at a later stage of Tumshuqese. See the alternation of $<\mathrm{au}>$ and $<_{\mathrm{o}}>$ attested in the following words: Tumsh. ustamatau [HL 16.49], ustamato [HL 16.36, 58], ustamad 10 [HL 10.11] 'even, finally' and gaursu [H111.4, 5], gaursā [or gorsā in H111.4], gorsi [HL 29.3, 6, 7, H111.6] 'name of food or cereal(?)', the latter of which was read as gautsu, gautsā, gautsi respectively by Duan (Duan 2021: 5).

4 The meaning 'harm' was supposed by Hitch (1992: 93), who compares it to Khot. $d \bar{u}$ 'harm'.

${ }^{5}$ In my discussion on Tumsh. $\chi$ šandaa- 'lord, ruler' (Ogihara 2020: 20-21) I quoted three attestations from HL 10, which can be regarded as a letter or a report addressed to a monastery official. In this case, Tumsh. tepi at the beginning of this document may be a borrowing from Chin. 牒 dié (EMC *dep; LMC *thiap, on the reconstruction of EMC and LMC, see Pulleyblank 1991), a certain kind of Tang official document or 帖 $t i e ̌ ~\left(E M C ~ * \mathrm{t}^{\mathrm{h}} \varepsilon \mathrm{p}\right.$; LMC $* \mathrm{t}^{\mathrm{h}}$ iap), a simplified form of 牒 dié and less formal in use', cf. Kuch. tep (Ching \& Ogihara 2010: 108). Thus, the passage HL 10.1: tepi pese aśrā kșemayeśā be translated as 'the document for the teacher, ācārya, Kșemayaśa(s)'. On the other hand, Bailey proposed tentatively the meaning 'teacher(?)' to Tumsh. tepi (SDTV I: 47).
} 


\section{2-2. Tumsh. $\operatorname{hodad}_{1} a$ 'seventy'}

Another numeral appears in the following passages in the same document treated in the preceding section.

HL 29b1: ] ka + ×i mure rorama hodad ${ }_{1} a \mid$ 'We give money to [...], 70.'

HL 29b2: ] rorama hodad 1 ä pantsi |'We give [...], 75'.

Although Tumsh. hodad 1 a/hodad $\ddot{1}$ a has never been recognized by scholars, it is the numeral 'seventy', as suggested by the corresponding Khotanese form, haudātä/hodātä 'seventy'. If this is accepted, Tumsh. hodad ${ }_{1} \ddot{a}$ pantsi should indicate 'seventy five'.

In addition, Tumsh. pantsas $\ddot{a}$ attested in the next line should be a variant for the numeral patsasu 'fifty'.

HL 29b3: ] + aśanu mure rorama, pantsasä

'[...] We give money for horses, 50'.

\section{2-3. Tumsh. $\operatorname{sod}_{1} u$ 'hundred'}

In my latest article on the Tumshuqese, I proposed that Tumsh. azaru(sg.)/zare(pl.) would be the numeral for 'thousand' (Ogihara 2020: 18-20). In the discussion, I mentioned that only the plural form $\mathrm{sad}_{1} e$ is attested for the numeral for 'hundred'. However, the detailed research on the Tumshuqese materials leads to the supposition that Tumsh. $\operatorname{sod}_{1} u$ would be the singular form for the numeral 'hundred'. To my knowledge, Tumsh. $\operatorname{sod}_{l} u$ is attested thrice.

HL 11.1: $a k^{h} a \operatorname{șad}_{1} a \operatorname{sod}_{1} u$ mare $k^{h} o$

'[...] ?-ed(3sg./pl.) [...] 100(?) $k^{h}$ aas.'

HL 11.3: pa-wa $k^{h}$ alire $\operatorname{sod}_{1} u k^{h} o \bar{a} d_{1} a$

'And then, $k^{h}$ alire arrived, 100(?) $k^{h}$ aas.'

HL 32.7: [ca. 4 akșaras] $+r r \times \operatorname{sod}_{1} u$ azarū be ma le $\times r \times[$

'[...] 100, 000(?) woven cloths(?) [... $]^{8}$

The context of these attestations is so obscure that it is not easy to propose the exact interpretation. However, Tumsh. $\operatorname{sod}_{1} u$ precedes azaru 'thousand' in HL 32.7, which is comparable to Khot. satä-ysāra- 'a hundred thousand' (Skjærvø 2004: 351b). In addition, it is

\footnotetext{
${ }^{6}$ As will be discussed in the section 3-2 below, Tumsh. $k^{h} a a$ - is very probably a word of measure, not a commercial item as suggested (Ogihara 2020: 19, fn. 34). In this passage, the main verb $a k^{h} a s a_{1} a$, of which exact meaning cannot be restored, is the $3 \mathrm{sg} . / \mathrm{pl}$. impf.-inj. mid. The obscure context does not permit me to decide the grammatical status of mare in this passage.

${ }^{7}$ Although Tumsh. $k^{h}$ alire can be regarded as the subject of $\bar{a} d_{1} a$ 'came(3sg./pl.)', the number and gender of $k^{h}$ alire depends on the interpretation of $\bar{a} d_{l} a$. If $\bar{a} d_{l} a$ is the f. sg. form, it is the f. sg. noun. On the other hand, it is the pl. noun in case that $\bar{a} d_{l} a$ is the m. pl. form. Because it is not possible to decide which is correct, I am obliged to leave it open. If my interpretation of $\operatorname{sod}_{l} u$ and $k^{h} o$ is correct, it should be a common noun. Still, the meaning of Tumsh. $k^{h}$ alire remains uncertain. In interpreting the new attestation of this noun in a thus far unknown Tumshuqese document found in China (the inventory number: H111), it is interpreted as 'prince' (Duan 2021: 7-8), based on Bailey's proposition (SDTV I: 47) that it is a proper name, and the comparative study with the documents written in Niya Prākrit and Bactrian. However, the context of this passage in $\mathrm{H} 111$ is too obscure to support the interpretation 'prince'.

${ }^{8}$ This fragment is preserved in IOM, RAS. The present inventory number is SI Khot.954 (the previous numer: SI B/10-1). It is uncertain whether Tumsh. bema is the cognate of Khot. bema- 'woven cloth' (DKS: 303b). Tumsh. bema is attested in H111.10 (cf. Duan 2021: 14), who translates this noun as 'wealth'.
} 
used with the sg. acc. of Tumsh. $k^{h} a a$ - in HL 11.1 and 11.3 which usually indicates the quantity of a noun accompanied by a numeral. Taking these attestations into account, Tumsh. $\operatorname{sod}_{1} u$ could be most naturally explained as 'hundred', cf. Sogd. stw/satu/ 'hundred' (Gharib 1995: 363b). It is remarkable that Tumsh. $\operatorname{sod}_{l} u$ has the neuter ending $-u$ as the Sogdian form stw /satu/ comparable to Av. satzm 'hundred'. In summary, the numerals 'hundred' and 'thousand' exhibit the same declension in Tumshuqese in difference to Khotanese.

$\begin{array}{lll} & \text { 'hundred'(sg./pl.) } & \text { 'thousand'(sg./pl.) } \\ \text { Tumshuqese } & \operatorname{sod}_{1} u: \text { sad }_{1} \text { e } & \text { azaru }: \text { zare } \\ \text { Khotanese } & \text { satä }: \text { sate } & \text { ysāru }: \text { ysāre }\end{array}$

In Tumshuqese, the ending $-u$ is used for the singular form of both numerals, and the ending $-e$ is assigned to the plural form. On the other hand, the Khot. numeral 'hundred' shows the ending $-\ddot{a}$ in the singular form.

\section{2-4. Tumsh. $d_{r d} a$ - 'third'}

In the Tumshuqese contracts, the date of a transaction is clearly mentioned at the beginning. It refers to the day, the month and the regnal year of the Gūzdik king, to which most of our knowledge on the Tumshuqese ordinals owes. In the course of our decipherment of TX001-004, we encountered the ordinal 'third'. As mentioned in TPR: 77, the Tumsh. ordinal $d r d_{l} y e$ 'third' first given by Ogihara and Ching (Ogihara \& Ching 2013: 46, 47, 55) was corrected to $d r d_{l} w e$, based on the suggestion by Maue.

In her edition of two recently found Tumshuqese documents, Duan proposes the reading $d r d_{1} d e$ to the above mentioned form in the light of a newly attested $d r d_{1} t e$ 'third' in the Tumshuqese contract H111 and Khot. däda-/dädda- 'third' (Duan 2021: 7, 11).

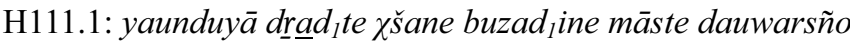

'In the 3rd regnal year of Yondu, in the $\operatorname{Buzad}_{1}$ (ina) month, on the 13th day'10

However, the scrutiny on the plate of this fragment attached to her paper in which Tumsh. $d r d_{1}$ te appears enables me to offer another possible interpretation to the Tumsh. ordinal 'third'.

As mentioned by Duan (Duan 2021: 7), the second akșara of $<\operatorname{drd}_{1}$ te $>$ can also be read as $<\mathrm{d}_{1} \mathrm{ne}>{ }^{11}$ In my opinion, this form should be $d r d_{1} n e$, of which original form is $d r d_{1}$ ane,

\footnotetext{
${ }^{9}$ In TX001a7 and a8, Tumsh. $b \bar{a} g_{2} e$ is attested twice, to which the translation 'management' was given (Ogihara \& Ching 2014: 30; 2017: 463). In addition to these attestations in TX001, it also appears in HL 11.7, 9 and HL 32.3. Taking into account that Tumsh. $b \bar{a} g_{2} e$ follows the gen.-dat. form of a noun in these attestations, it may be a postposition 'instead of, for the sake of' as a cognate of Khot. bāje, bāja (SVK I: 86 and III: 112-114).

${ }^{10}$ Here I corrected dauwa[rsañyo] 'thirteeen' read by Duan (Duan 2021: 5) to dauwarsño, see infra.

${ }^{11}$ Although we have two more attestations of $<\mathrm{d}_{1}$ te $>$ in H111.7 and 111.9, the correct reading of these forms should also be $<\mathrm{d}_{1}$ ne $>$, namely H111.7: $<\operatorname{lāzid}_{1}$ ne $>$ and 111.9: $<$ bidruhvid $_{1}$ ne $>$. These are the infinitives with the vowel reduction in the penultimate syllable of lāz- 'meaning unknown' and bidruhv- 'to misbehave(?)' respectively. The expected forms are lāzid ${ }_{1}$ ane and bidruhvid ${ }_{1} a n e$, cf. parādlane, parād ${ }_{1} \ddot{a} n e$, and parād $_{1}$ ne attested as the infinitive of parat $^{h}-/$ parā $_{1} a$ - 'to sell'. Although the insufficient documentation of Tumshuqese does not leads to the detailed description of the Tumsh. verbal system, Tumsh. verbs can be classified to four, mainly, two Classes as in Khotanese (Ogihara 2019: 299-302). Class A in Tumshuqese has $-i$ - between stem and ending for the $3 \mathrm{sg}$. prs. act./mid., which corresponds to $-\ddot{a}$ - of Khot. Class A. On the other hand, this $-i$ - does not appear in Tumsh. Class B as in Khot. Class B, thus, stem directly followed by ending. The insertion of $-i$ - also applies to the $3 \mathrm{sg}$. imper. act. and past stem of Class A, the latter of which goes back to the past passive participle of Old Iranian in *-ta. In the impf.-inj. in Tumshuqese, the distinction between Classes $\mathrm{A}$ and $\mathrm{B}$ is reflected by the different endings, namely $3 \mathrm{sg}$. mid.: -ta/-da; 3pl. mid.: -anda are restricted to Class B, although the ending 3sg./pl. mid.: $-a d_{1} a$ applies to both Classes.
} 
the m. sg. loc. of $d r d_{1} a$ - as suggested by Tumsh. dritana 'thrice', the sg. instr.-abl. of drita(Bailey 1950: 653). ${ }^{12}$ Moreover, Tumsh. bid ${ }_{1}$ ane attested in TX001a1 and b9, the m. sg. loc. form of $\operatorname{bid}_{1} a$ - 'second', lends support to $d r d_{1}$ ne with the vowel reduction in the penultimate syllable which goes back to $d r d_{1} a n e .{ }^{13}$ Thus, the above quoted passage should

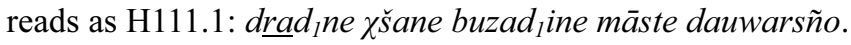

If this is accepted, Tumsh. $d r d_{1} w e$ we read in TX001 and 003 should be reconsidered. I would rather like to read this form as $<\mathrm{drd}_{1}$ nye $>$ with $<\mathrm{y}>$ indicating the palatalization of a preceding $/ \mathrm{n} /$ caused by the ending $-e$ as follows.

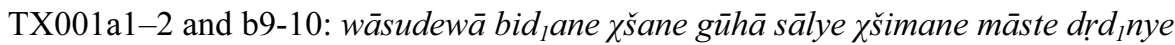

'In the 2nd regnal year of Wāsudewa, the year of ox, in the 6th month, on the 3rd day.'

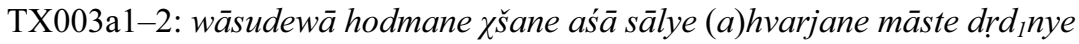

'In the 7th regnal year of Wāsudewa, the year of horse, in the Ahvarjana month, on the 3 rd day, 14

The problem is that the akșara $<$ nya $>$ written below $<\mathrm{d}_{1} \mathrm{a}>$ is different from the usually attested form, and it rather resembles $<$ wa $>$. In the ligature $<$ nya $>$ composed of $<$ na $>$ and $<$ ya $>,<$ na $>$ deletes the botttom stroke and only leaves the upper part, to which the $<$ ya $>$ specific to the ligature is attached. ${ }^{15}$ What is important is that the akșara $<$ na $>$ is never written in its full form as the first component of a ligature. On the other hand, <na $>$ is written almost in its full form as the second component.

Now it is possible to suppose that the scribe of TX001 and 003 would have used the normal $<$ na $>$ as the second component to write the ligature $<\mathrm{d}_{1}$ na $>$ first, and added the $<$ ya $>$ specific to the ligature to this $<\mathrm{d}_{1}$ na $>$ as the third component. Consequently, the ligature $<$ nya $>$ in $<\mathrm{d}_{1}$ nya $>$ is different from the usually attested $<$ nya $>{ }^{16}$ If it is correct, Tumsh. $d r d_{1} n e$ and $d r d_{1}$ nye can be set up as the m. sg. loc. form of the ordinal $d r d_{1} a$ - 'third'.

\section{Words of measure}

\section{3-1. Tumsh. jaha-}

In the fragment preserved in the Paris collection, the hapax jhā appears. ${ }^{17}$

HL 30a5: ] risa bari 2 jhā | [...] brought(3sg.) [...], 2 jahas'.

To my knowledge, the verb hvan- 'to speak' is the exception to these rules (cf. hvan- 'to speak': 3sg. act. prs. hvanid $_{1} i / h v a \tilde{n} i d_{1} i$, past stem: hvata-/hvad ${ }_{1}$-). Tumsh. infinitives are based on the past stem. Consequently, Tumsh. lāzid ${ }_{1} n e\left(<\operatorname{lāzid}_{1} a n e\right)$ attested in H111.7 derives from lāzid ${ }_{1} a-$, the past stem of the verb lāz-. The present stem $l \bar{a} z$ - is confirmed by the agent noun lāzāki (TX003a4).

${ }^{12}$ Concerning the m. sg. loc. ending -ane, see (Maggi 1991: 221-224).

${ }^{13}$ The vowel reduction in the penultimate syllable is also observable in dauwars ño (or dowarsño) 'twelve' in H111.1, which was read as dauwa[rsañyo] (Duan 2021: 5), cf. dowarsañy(o) without the vowel reduction attested in HL 33.2 .

${ }^{14}$ The translation 'In the 2nd regnal year of Wāsudewa' at the beginning of TX003 given in (Ogihara \& Ching 2017: 465) should be corrected as here.

${ }^{15}$ For the Brāhmī script developped in the northern rim of the Tarim basin (Malzahn 2007).

${ }^{16}$ At present, the lack of other attestations does not permit me to decide whether this is the normal writing style for $<\mathrm{d}_{1}$ nya $>$ in the Tumshuqese or not.

${ }^{17}$ The faint trace of a vowel diacritic sign above $<$ jha $>$ at the beginning of line a 2 of the same document permits us to restore $j h(\bar{a})$. The vertical line after this akșara indicates that this passage ends with this akșara as line a5 quoted here. 
In my opinion, this form should be the m. pl. nom.-acc. form of jaha-. Tumsh. jaha- has been recognized since the pioneering work by Konow (Konow 1935: 818; Konow 1947: 183 ), according to whom it would mean 'how, that'. However, the context suggests that it can be safely interpreted as a word of measure.

HL 7.1: $k^{h}$ așo $g_{2}$ i latsāñgi yesi mo bari jahu nä

'Latsāngi came(?) from Kāš(?). He brought wine, 9 jahas' ${ }^{18}$

In this attestation, the sg. acc. form of jaha- is used to indicate the quantity of liquid. ${ }^{19}$ As well as in Khotanese (Emmerick 1965: 25), the usage of the nominative case as measure is known to Tumshuqese as pointed out by Hitch (Hitch 1987: 59-60).

HL 6.5-6: dad ${ }_{1}$-hvana dād $d_{1} u$ hvañi lāwu yi $k^{h} \bar{a} l i$ rorama śo soli

'The preacher is scheduled to preach a law. We give oilcake paste(?) as a donation/tribute(?) to him, one sola' ${ }^{20}$

In this passage, Tumsh. soli is the m. sg. nom. form of sola-, and its plural form sole is also attested in HL 6.2, 7.3 and 7.4. Thus, Tumsh. jha in HL 30a5 introduced here can also be interpreted in the same line of thought. The vowel reduction in the first syllable and lengthening of the final vowel can be supported by howa attested in TX002a9, as a variant of the sg. nom. form $h v \bar{a}$ of $h v a r-$ 'sister'.

Furthermore, the interpretation of Tumsh. $j h \bar{a}$ as the m. pl. nom.-acc. form of jaha- could lead to a better understanding of the final word in the following sentence which has been read and interpreted differently.

HL 4.13: bije śeñcu sud ${ }_{1}$ ati [SIG] hampara-ñijane șe mo rahuho jhā

'Witness, Śeñcu, Sud $_{1}$ ati. [SIG] ${ }^{21}$ Wine to(?) the hampara's [...], rahuho jahas' ${ }^{22}$

These sentences appear in the list of witnesses of the contract. The last akșara of the latter sentence has been interpreted in two different ways, namely as a verbal form and as a signature. Konow proposed $<$ jāha $>$ (Konow 1935: 808, 818) and $<$ jeha $>$ (Konow 1947: 168, 183 ) as a verbal form of $2 \mathrm{sg}$. imper. act. of $j \bar{a} h$ - 'to clean'. On the other hand, Hitch and Maue regard it as a signature, although their readings are different from each other: $<j \bar{a}+$ ha $>$ (Hitch 1985) and <jhe $>$ (Maue 2009).

However, the last akșara can also be read as $\langle$ jhā $>$. In addition, this line seems to be written in the same hand, and the signatures in the Brāhmī script given in this contract are rotated 90 degrees counterclockwise just like $<\mathrm{su}>$ in the preceding part of HL 4.13 quoted here (transliterated as [SIG]). These signatures and $<$ jhā $>$ are written in different hands

\footnotetext{
${ }^{18}$ I regard Tumsh. $k^{h}$ aṣo as the pl. instr.-abl. of $k^{h} a s ̣ a-$ 'Kāšs(?)' tentatively, cf. Khot. khyeșa- 'Kāš (KT VII: 50-54)'.

${ }^{19}$ Tumsh. jahu also appears in HL 7.2 and 7.3. Furthermore, Tumsh. jahä attested in HL 29a3 can be taken as a variant of jahu.

${ }^{20}$ Tumsh. $k^{h} \bar{a} l i$ may be a loan word from BHS khali- 'oil-cake' (BHSD: 204a). I regard Tumsh. lāwu as a borrowing from an unattested Bactrian *lā-(?), cf. OA dāh- 'gift' introduced above.

${ }^{21}$ Tumsh. śeñcu was regarded as 'a Chinese title' (Konow: 1935: 808-809, 811, 822), or 'name, or surname of a man' (Konow 1947: 168-169, 170, 188). On the other hand, Tumsh. sud ani read by Konow (op. cit.) was rejected by Hitch (1985) and Maue (2009), which I follow here. Tumsh. śeñcu sudiati appears as sud $_{1}$ ati śeñcu in HL 6.3. In my opinion, Tumsh. śeñcu would be a title. The signature <su>confirms that Tumsh. sud $_{1}$ ati is a personal name.

${ }^{22}$ The exact meaning of Tumsh. hampara- is ambiguous. Konow (1935: 817 and 1947: 189) and Bailey (1958: 152-153) regard it as 'store, storehouse'. On the other hand, the interpretation of hampara- as 'object that brings yearly profit' was proposed by Ching Chao-jung in the course of our decipherment of TX001-004, cf. TPR: 85, Ogihara \& Ching (2014: 24 and 2017: 471).
} 
evidently. If this is the case, the latter interpretation as a signature should be reconsidered. The fact that Tumsh. mo 'wine' appears here suggests that $<$ jhā $>$ attested in this passage would be very probably the m. pl. nom.-acc. form of jaha-. In this case, rahuho preceding it would be a thus far unknown numeral which indicates plurality. ${ }^{23}$

\section{3-2. Tumsh. $k^{h} a a-$}

As briefly mentioned in the footnote in the section $2-3$ above, Tumsh. $k^{h} a a$ - is very probably a word of measure, not a commercial item as suggested in Ogihara (Ogihara 2020: 19, fn. 34). In most of the attestations, it appears as the sg. acc. form, $k^{h} o$ (in total 16 times). The nominative form is $k^{h} a / k a$ [HL 38.2, 38.3], and $k^{h}$ ayo [HL 11.15] can be assigned to the pl. instr.-abl. form. The sg. acc. form $k^{h} o$, usually accompanied by a numeral, indicates the quantity of a noun. Below are quoted some attestations that exemplify well its usage.

HL 10.14: śida $k^{h}$ o 50 mre 5 ka 1000 bārre 10

'Śida (received?) $50 k^{h}$ aas, 5000 murās, 10 bārrās'.

HL 11.1: $a k^{h} a \operatorname{șad}_{1} a \operatorname{sod}_{1} u$ mare $k^{h} o$

'[...] ?-ed(3sg./pl.) [...] 100(?) $k^{h}$ aas'.

HL 11.3: mare $k^{h} \circ *$ cilye rorama

'Here we give $1 k^{h}$ aa as cila'.

HL 11.3: pa-wa $k^{h}$ alire $\operatorname{sod}_{1} u k^{h} o \bar{a} d_{1} a$

'And then, $k^{h}$ alire arrived, 100(?) $k^{h}$ aas'.

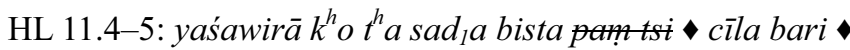

'He brought $120 k^{h}$ aas of cila to Yaśawira'.

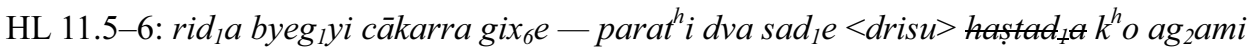
$++<105>[(+)] g_{1} \times[(+)]$ ri bari

'[...] Cākarra sold sheep(?) [...] $230 k^{h}$ aas [...] 15 [...] brought(3sg.) [...]'

HL 11.25: briyalka $k^{h}$ o rori sa 10 cila ñesta

'Briyalka gave [...] $1 k^{h}$ aas, and received 10 cilas.'

HL 11.26: śo $k^{h}$ o we lakana gr (nda) | kuṇdi $g_{1}$ a șe |

'A pot was bought from Laka, $1 k^{h} a a^{2}$.

As the above attestations reveal, Tumsh. $k^{h} o$ indicates the quantity of a noun, accompanied by a numeral.

As for the classification of the stem of this noun, it can be regarded both as the $-\bar{a}-$ stem noun and as the -aa-stem noun, for these two nominal classes have the same endings: the sg. nom. $-a$ and sg. acc. $-o$ (the original form being $-a u$ for the $-a a$ - stem nouns). However, since Tumsh. $-\bar{a}$ - stem nouns have $-y o$ as the pl. instr.-abl. ending, cf. bisyo [HL 2.8] for bis $\bar{a}$ - 'house', the pl. instr.-abl. form $k^{h}$ ayo suggests that it would be classified to the -aa-stem noun. ${ }^{25}$ Thus, the stem form of $k^{h} \bar{a}$ - (Ogihara 2020: 19, fn. 34) should be abandoned.

\footnotetext{
${ }^{23}$ Even if this is accepted, it is still not easy to interpret the interrelationship between these two sentences.

${ }^{24}$ Tumsh. kuṇ̣i would be a loan word from Indic languages, cf. Skt. kunḍin- 'a kind of vessel' [MW: 290a].

${ }^{25}$ On the other hand, the sg. instr.-abl. ending of the -aa-stem nouns is -ona/-ona $\bar{a}$, cf. mitrona $<$ mitraa'Maitreya', pesonā < pesaa- 'teacher', and brikanonā < brikanaa- 'personal name'.
} 


\section{Concluding remarks}

In this paper, I interpreted some words appeared in the Tumshuqese secular documents. My discussion mainly concerns the Tumshuqese numerals together with words of measure. Among them, Tumsh. tshärsa 'forty', hodad ${ }_{1} a$ 'seventy', $\operatorname{sod}_{1} u$ 'hundred', and $d r d_{1} a-$ 'third' deserve to be mentioned. These forms resemble the corresponding Khotanese forms, tcaholsä/tcoholsä, haudātä/hodātä, satä, and däda-/dädda- respectively. Still, they show the peculiarities in phonetic changes and the morphology in Tumshuqese. Although the documents belong to the best preserved materials in Tumshuqese, the attestations are so scarce that it is not easy to draw a decisive conclusion. Not only comparative research but also detailed examination of context of the texts will be required to elucidate unsolved problems.

\section{Addendum}

After my submission of this contribution, Dr. Dieter Maue kindly informed me that $<$ hvid $_{1}$ ne $>$ attested in H111.9 should be interpreted as $<$ bidruhvid $_{1}$ ne $>$, the infinitive of bidruhv- as quoted in p. 152, fn. 11 (p.c. email on 24 August 2021). I would like to express my deepest gratitude to him for his remarks. We are preparing the re-edition of two Tumshuqese documents H111 and H112 published by Duan (Duan 2021).

\footnotetext{
Abbreviations

AV. - Avesta

BHS - Buddhist Hybrid Sanskrit

EMC — Early Middle Chinese

Khot. - Khotanese

Kuch. - Kuchean

LMC — Late Middle Chinese

OA — Old Avesta

Sogd. - Sogdian

Tumsh. - Tumshuqese

BHSD - Edgerton, Franklin. Buddhist Hybrid Sanskrit grammar and dictionary. Vol. II: Dictionary.

New Haven: Yale University Press, 1953 (in English).

DKS — Bailey, H. W. Dictionary of Khotan Saka. London: CUP, 1979 (in English).

KT VII - Bailey, H. W. Khotanese Texts. Volume VII. Cambridge: CUP, 1985 (in English).

MW - Monier-Williams M. Sanskrit-English Dictionary: Etymologically and Philologically Arranged. Oxford: Clarendon, 1899 (in English).

SDTV I - Bailey, H. W. Saka Documents. Text Volume (Corpus Inscriptionum Iranicarum. Pt. II: Inscriptions of the Seleucid and Parthian Period and of Eastern Iran and Central Asia. Vol. V: Saka.). London: Lund Humphries, 1968 (in English).

SVK I - Emmerick, R.E., P.O. Skjcervø. Studies in the Vocabulary of Khotanese I (Österreichische Akademie der Wissenschaften, Philosophisch-Historische Klasse, Sitzungsberichte, 401. Bd.). Wien: Verlag der Österreichischen Akademie der Wissenschaften, 1982 (in English).
} 
SVK III - Emmerick, R.E., P.O. Skjoervø. Studies in the Vocabulary of Khotanese III (Österreichische Akademie der Wissenschaften, Philosophisch-Historische Klasse, Sitzungsberichte, 651. Bd.). Wien: Verlag der Österreichischen Akademie der Wissenschaften, 1997 (in English).

TPR - Bureau of Cultural Relics of Tumshuk City 圖木舒克市文物局, Center for Research on Ancient Chinese History, Peking University 北京大學中國古代史研究中心, Institute for Historical and Philological Studies of China's Western Regions, Renmin University of China 中國人民大學 國學院西域歷史語言研究所. Sanjian xinchu jushideyu qiyue 三件新出據史德語契約 [Three Newly Found Tumshuqese Sale Contracts], Xiyu lishi yuyan yanjiusuo jikan 西域歷史語言研究 所集刊 [Historical and Philological Studies of China's Western Regions], 2014. Vol. 7. pp. 63105 (in Chinese).

\section{References}

Bailey, H.W. "The Tumshuq Karmavācanā". Bulletin of the School of Oriental and African Studies, 1950, vol. 13, no. 3, pp. 649-670, 809-810 (in English).

Bailey, H.W. "Languages of the Saka". Ed. by K. Hoffmann, W.B. Henning, H.W. Bailey et al. Handbuchder Orientalistik. 4. Bd. Iranistik; 1. Abschnitt: Linguistik. 1958. Leiden: E.J. Brill, pp. 131154 (in English).

Ching Chao-jung 慶昭蓉. “The Four Cardinal Directions in Tumshuqese”. Ed. by Pavel B. Lurje. Proceedings of the Eighth European Conference of Iranian Studies, vol. 1, 2019. St. Petersburg: State Hermitage Publishers, pp. 66-86 (in English).

Ching Chao-jung 慶昭蓉, Ogihara Hirotoshi 荻原裕敏. “Internal Relationships and Dating of the Tocharian B Monastic Accounts in the Berlin Collection". Nairiku ajia gengo no kenkyu 内陸ア ジア言語の研究 [Studies on the Inner Asian Languages], 2010, vol. 25, pp. 75-141 (in English).

Duan Qing 段晴. “Huang Wenbi faxian de liang jian jushideyu wenshu” 黃文㢱發現的兩件據史德 語文書 [Two Gūzdiya Documents Discovered by Huang Wenbi]. Xiyu wenshi 西域文史 [The Western Regions Literature and History], 2021, vol. 15, pp. 1-18 (in Chinese).

Emmerick, R.E. "Syntax of the Cases in Khotanese". Bulletin of the School of Oriental and African Studies, 1965, vol. 28, no. 1, pp. 24-33 (in English).

Gharib, B. Sogdian Dictionary: Sogdian-Persian-English. Tehran: Farhangan Publications, 1995 (in English).

Hitch, D.A. Tumshuqese Transcriptions, 1985. Wateringen (in English).

[https://www.researchgate.net/publication/329030821_Tumshuqese_Transcriptions (Last access: 2021/8/4)].

Hitch, D.A. "Tumshuqese and Tocharian Word of Measure". Tocharian and Indo-European Studies, 1987, vol. 1, pp. 59-62 (in English).

Hitch, D.A. "Penalty Clauses in Tumshuqese, Khotanese and the Shanshan Prakrit". Studia Iranica, 1988, Vol. 17, pp. 147-152 (in English).

Hitch, D.A. "Prakrit Administration at Tumshuq". Paper read at the 33rd ICANAS. 1990 [https:// www.researchgate.net/publication/320291220_Prakrit_Administration_at_Tumshuq (Last access: 2021/8/4)] (in English).

Hitch, D.A. "Tumshuqese reșth- (reșth-): Khotanese *hișt- 'send'”. Journal of Turkish Studies, 1992, vol. 16, pp. 91-95 (in English).

Konow, Sten. "Ein neuer Saka-Dialekt". Sitzungsberichte der Preussischen Akademie der Wissenschaften. Philosophisch-Historische Klasse. 1935. Berlin: Verlag der Akademie der Wissenschaften, Jahrgang ,1935, pp. 772-823 (in German).

Konow, Sten. "The Oldest Dialect of Khotanese Saka". Norsk Tidsskrift for Sprogvidenskap, 1947, Bind 14, pp. 159-190 (in English).

Maggi, Mauro. "Note tumšuqesi". Studia linguistica amico et magistro oblata: Scritti di amici e allievi dedicati alla memoria di Enzo Evangelisti (Quaderni della collana di linguistica storica e descrittiva 3). Milano: Unicopli, 1991, pp. 219-228 (in Italian). 
Malzahn, Melanie. "The Tocharian Brahmi Chart”. Ed. by Melanie Malzahn. Instrumenta Tocharica. Heidelberg: Winter, 2007, pp. 223-254 (in English).

Maue, Dieter. Corpus of Tumshuqese Fragments: Introduction, Handlist, Transliteration. TITUS (Thesaurus Indogermanischer Text- und Sprachmaterialien), 2009 [http://titus.uni-frankfurt.de/ indexe.htm (Last access: 2021/8/4)] (in English).

Maue, Dieter, Ogihara Hirotoshi 荻原裕敏. “Tumschukische Miszellen III: 3. Tumshukese Dental Affricates". Ed. by Turfanforschung. Zur lichten Heimat. Gedenkschrift für Werner Sundermann. 2017. Wiesbaden: Harrassowitz. pp. 421-432 (in German).

Ogihara Hirotoshi 荻原裕敏. “Roshia shozo Tokarago bunken ni kansuru oboegaki” ロシア所蔵卜 カラ語文献に関する覚え書き [Remarks on the Tocharian Manuscript Remains Housed in the Russian Collection]. Tokyo daigaku gengogaku ronshu denshiban (eTULIP) 東京大学言語学論 集 電子版 (eTULIP) [Tokyo University linguistic papers (eTULIP)]. 2018. pp. e1-e41 [https:// doi.org/10.15083/00076315] (in Japanese).

Ogihara Hirotoshi 荻原裕敏. “Tumshuqese Imperfect and Its Related Forms". Ed. by Pavel B. Lurje. Proceedings of the Eighth European Conference of Iranian Studies, vol. 1, 2019. St. Petersburg: State Hermitage Publishers, pp. 297-309 (in English).

Ogihara Hirotoshi 荻原裕敏. "Miscellany on the Tumshuqese documents". Central Asiatic Journal, 2020, vol. 63, no. 1-2. pp. 11-24 (in English).

Ogihara Hirotoshi 荻原裕敏. "She ji ji ren de zizai wangzi-Vessantara-jātaka zhi fan, han, qiuci, sute zhuben bijiao" 捨已濟人的自在王子—Vessantara-jätaka 之梵、漢、龜茲、粟特諸本比較 [Altruism of the All-subduing Prince: A Close Comparison of the Sanskrit, Chinese, Kuchean and Sogdian Versions of the Vessantara-jātaka]. Ed. by Zheng Acai 鄭阿財, Wang Juan 汪娟. Zhang Guangda xiansheng jiushi huadan zhushou lunwenji 張廣達先生九十華誕祝壽論文集. 2 vols. Taibei: Xinwenfeng chuban 新文豐出版, 2021, pp. 985-1022 (in Chinese).

Ogihara Hirotoshi 荻原裕敏, Ching Chao-jung 慶昭蓉. “Xinchu Jushideyu siyuan qiyue wenshu ji qita” 新出據史德語寺院契約文書及其他 [A Newly Found Tumshuqese Monastic Contract and Other Related Findings]. Xiyu wenshi 西域文史 [The Western Regions Literature and History], 2013, vol. 7, pp. 43-61 (in Chinese).

Ogihara Hirotoshi 荻原裕敏, Ching Chao-jung 慶昭蓉. “Xinshutsu Tumushukugo kēyaku monjo ni tsuite” 新出トゥムシュク語契約文書について [On the Tumshuqese Contracts Newly Published in China]. Nairiku ajia gengo no kenkyu 内陸アジア言語の研究 [Studies on the Inner Asian Languages], 2014, vol. 29, pp. 7-55 (in Japanese).

Ogihara Hirotoshi 荻原裕敏, Ching Chao-jung 慶昭蓉. “Some Observations on the Tumshuqese Documents Newly Published in China". Ed. by Turfanforschung. Zur lichten Heimat. Gedenkschrift für Werner Sundermann. Wiesbaden: Harrassowitz, 2017, pp. 453-482 (in English).

Pulleyblank, E.G. Lexicon of Reconstructed Pronunciation in Early Middle Chinese, Late Middle Chinese, and Early Mandarin. Vancouver: UBC Press, 1991 (in English).

Skjærvø, Prods O. This Most Excellent Shine of Gold, King of Kings of Sutras, the Khotanese Suvarnabhāsottamasūtra. Volume II: Manuscripts, Commentary, Glossary, Indexes. (Sources of orien 慶昭蓉. "Some Observations on the Tumshuqese Documents Newly Published in China". Ed. by Turfanforschung. Zur lichten Heimat. Gedenkschrift für Werner Sundermann. Wiesbaden:tal languages and literatures, 61. Central Asian sources; 6). Cambridge, MA: Harvard University Press, 2004 (in English). 


\title{
Сборник документов на тумшукском языке: Часть II
}

\author{
Хиротоси ОГИХАРА
}

Токио, Япония

Статья поступила в редакцию 03.06.2021.

Аннотация: Настоящая статья является продолжением серии работ по тумшукскому языку (часть I см.: Central Asiatic Journal, 2020, vol. 63, no. 1-2. pp. 11-24). Исследования тумшукского языка, одного из среднеиранских языков, идут сравнительно медленно из-за недостатка письменного материала, а также отсутствия параллельных текстов, которые могли бы дать почву для сравнительного анализа. Однако гражданские документы, особенно различные контракты, являются крайне важным источником для лингвистического анализа языка, так как во-первых, контракты на тумшукском языке лучше всего сохранились, а во-вторых, некоторые части этих контрактов можно сравнить с подобными контрактами на других центральноазиатских языках. В настоящей статье делается попытка проанализировать некоторые тумшукские слова, встречаемые в гражданских документах, например, числительные tshārsa «сорок», hodad $a$ «семьдесят», $\operatorname{sod}_{1} u$ «сто», $d r d_{1} a$ - «третий», меры jaha- и $k^{h} a a-$ к существительному dau/do «подарок». Среди этих слов числительные tshärsa «сорок» и $h_{0} d_{a} d_{1} a$ «семьдесят» встречаются впервые. Несмотря на то что другие слова были уже известны ученым, тем не менее в статье дается новая интерпретация их значения или анализ их использования.

Ключевые слова: среднеиранские языки, тумшукский язык, Центральная Азия, гражданские документы, контракты, числительные, слова мер.

Благодарность: Эта статья является выражением моей благодарности проф. Ирине Поповой за помощь в моей работе с центральноазиатскими фрагментами, хранящимися в Институте восточных рукописей РАН, которую я начал еще в 2008 г. Я также выражаю глубокую признательность проф. Дуань Цину, снабдившему меня электронным изданием двух недавно обнаруженных тумшукских текстов (Duan 2021).

Для цитирования: Огихара Хиротоси. Сборник документов на тумшукском языке: Часть II // Письменные памятники Востока. 2021. Т. 18. № 3 (вып. 46). С. 148-159 (на англ. яз.). DOI: $10.17816 / \mathrm{WMO} 77877$

Об авторе: ОГИХАРА Хиротоси, научный сотрудник Высшей школы гуманитарных исследований и социологии (лингвистика) Университета Токио (Токио, Япония). Центр исследований цивилизаций Восточной Азии (CRCAO), Париж, Франция (diyuanyumin@gmail.com). 